\title{
ASPARTATE AND GLUTAMATE AS POSSIBLE NEUROTRANSMITTERS IN THE VISUAL CORTEX ${ }^{1}$
}

\author{
ROBERT W. BAUGHMAN AND CHARLES D. GILBERT
}

Department of Neurobiology, Harvard Medical School, Boston, Massachusetts 02115

\begin{abstract}
To identify possible neurotransmitters in the visual cortex, high pressure liquid chromatography was used to measure the release of endogenous compounds from a tissue slice preparation of the visual cortex of the rat. When synaptic release was induced, either by raising the $\mathrm{K}^{+}$concentration in the medium or by adding veratridine, of the compounds measured, marked increases (6- to 35fold) in release rate were observed for aspartate, glutamate, and $\gamma$-aminobutyric acid (GABA). This increased release was blocked either with a low $\mathrm{Ca}^{2+} /$ high $\mathrm{Mg}^{2+}$ or a tetrodotoxin-containing medium. To label possible aspartate or glutamate pathways, $D-\left[{ }^{3} \mathrm{H}\right]$ aspartate and $\mathrm{D}-\left[{ }^{3} \mathrm{H}\right]$ glutamate were injected in the lateral geniculate nucleus (LGN), superior colliculus, and visual cortex. Following injections in the LGN, labeling was observed in the pyramidal cells in cortical layer 6 and in a diffuse band in layer 4, whereas no cortical cells were labeled after injections in the superior colliculus. When $\mathrm{D}-\left[{ }^{3} \mathrm{H}\right]$ aspartate was injected in the cortex, the uptake again was concentrated in the layer 6 cells, but no labeled cell bodies were seen in the LGN, confirming the specificity of the uptake and retrograde filling process. Diffuse labeling was present in the LGN, however, presumably produced by anterograde transport from the layer 6 cells.

These results suggest that layer 6 cells in the cortex, which are the source of the recurrent projection to the thalamus, may use aspartate or glutamate as their transmitter. Analysis of the function of the corticothalamic pathway may be facilitated by these findings.
\end{abstract}

Cells in each layer of the visual cortex have characteristic inputs, morphologies, functional properties, and projections. The input to the visual cortex from the lateral geniculate nucleus (LGN), for example, ends predominantly in layer 4 . Layers 2 and 3 are responsible for projections to other cortical areas, layer 5 for a projection to the superior colliculus, and layer 6 for a recurrent projection to the lateral geniculate nucleus (Gilbert and Kelly, 1975). Cells in each layer also participate in the internal circuitry of the cortex. To understand the role of any particular neuron in the analysis of visual information, it is necessary to know not only its receptive field properties and connectivity but its neurotransmitter as well. It is important to determine which transmitter is associated with each cell type and whether individual transmitters are involved with production of particular receptive field properties. While some progress has been made, suggesting that the transmitter employed by one class of smooth stellate cells is $\gamma$-aminobutyric acid (GABA) (Hokfelt and Ljundahl, 1972; Chronwall and

\footnotetext{
'We wish to thank Torsten Wiesel for support and encouragement, Lynn August, Hilary Hyatt, and John Kanki for technical assistance, and Kathy Cross for photography. This work was supported by $\mathrm{Na}$ tional Fye Institute Grants EY00606 and EY01995 and by the Medical and Sloan Foundations.
}

Wolff, 1978; Davis et al., 1977; Ribak, 1978), the identity of the transmitters used by other cells has not been established. Previous studies have suggested that, in addition to GABA, aspartate and glutamate may play a role as transmitters in cerebral cortex (see "Discussion"). In the present study, we have obtained further evidence that these compounds may have a neurotransmitter function, based on release of the endogenous compounds, and we have found that cells associated with aspartate and glutamate participate in the recurrent pathway from the cortex to the LGN. A preliminary report of this work has been published (Baughman and Gilbert, 1980).

\section{Materials and Methods}

Tissue slices. Tissue slices from rat visual cortex were prepared in the following manner. Rats were decapitated after cervical dislocation and blocks of visual cortex, approximately $3 \times 4 \mathrm{~mm}$, were removed and placed in a $0.9 \%$ agarose $/ \mathrm{Kreb}^{\prime}$ s solution at $37^{\circ} \mathrm{C}$. Each block was placed on the stage of a Sorvall tissue chopper in a $4^{\circ} \mathrm{C}$ cold room, and when the agar had hardened, slices of $200-\mu \mathrm{m}$ thickness were sectioned. The slices, approximately $30 \mathrm{mg}$, wet weight, were suspended in an Earle's salt solution $\left(143 \mathrm{mM} \mathrm{Na}^{+}, 5 \mathrm{mM} \mathrm{K}{ }^{+}, 1.8 \mathrm{mM} \mathrm{Ca}{ }^{2+}, 0.8\right.$ $\mathrm{mm} \mathrm{Mg}{ }^{2+}, 125 \mathrm{mM} \mathrm{Cl}{ }^{-}, 26 \mathrm{mM} \mathrm{HCO}{ }^{-}, 1.0 \mathrm{mM} \mathrm{H}_{2} \mathrm{PO}_{4}^{-}$, $0.8 \mathrm{mM} \mathrm{SO}_{4}{ }^{2-}, 5.5 \mathrm{~mm}$ glucose), gassed with $5 \% \mathrm{CO}_{2}, 95 \%$ 
air ( $\mathrm{pH} 7.4$ ) in a $37^{\circ} \mathrm{C}$ shaker bath, and incubated in a series of buffers of $5 \mathrm{ml}$ each with changes every $5 \mathrm{~min}$. For the high potassium-stimulated release experiments, the slices were incubated with three consecutive 5-min changes of normal medium followed by a 5-min "stimu" lated" incubation in high potassium $\left(50 \mathrm{~mm} \mathrm{~K}^{+}, 98 \mathrm{~mm}\right.$ $\mathrm{Na}^{+}$) medium. For the control release experiments, the slices were incubated with two 5-min changes of normal medium, followed by a 5 -min incubation in low calcium (0.1 $\mathrm{mM} \mathrm{Ca}^{2+}, 10 \mathrm{mM} \mathrm{Mg}^{2+}, 132 \mathrm{mM} \mathrm{Na}^{+}$) medium and a 5 -min "control" incubation in high potassium, low calcium ( $50 \mathrm{mM} \mathrm{K}{ }^{+}, 0.1 \mathrm{mM} \mathrm{Ca}{ }^{2+}, 10 \mathrm{~mm} \mathrm{Mg}{ }^{2+}, 87 \mathrm{mM} \mathrm{Na}^{+}$) medium. For the veratridine-stimulated release experiments, the slices were incubated with three consecutive 5 -min changes of normal medium followed by a 5 -min "stimulated" incubation in normal medium containing $100 \mu \mathrm{M}$ veratridine. In this case, for the control release experiments, the slices were incubated with two 5 -min changes of normal medium followed by a 5-min incubation in normal mediun containing $10 \mu \mathrm{M}$ tetrodotoxin and a 5-min "control" incubation in normal medium containing $100 \mu \mathrm{M}$ veratridine and $10 \mu \mathrm{M}$ tetrodotoxin. All buffer solutions contained $1 \mu \mathbf{M} n$-leucine as an internal standard. Rates of release, normalized to the weight of the tissue and the internal standard, were determined for 18 amino acids and the ratio of the rates of release were calculated for the "stimulated" versus "control" fractions.

Analysis of release. At the end of the incubation series, the sections were weighed, and the fractions from each buffer change were frozen in liquid nitrogen and lyophilized. For desalting, the residue was extracted with $4 \mathrm{ml}$ of $5 \% 6 \mathrm{~N} \mathrm{HCl}$ in acetone; after centrifugation, the supernatant was extracted with $8 \mathrm{ml}$ of iso-octane, followed by $4 \mathrm{ml}$ of diethyl ether. For analysis, an aliquot of the aqueous extract was taken to dryness with $\mathrm{N}_{2}$ and reconstituted in $0.2 \mathrm{~N} \mathrm{Na}^{+}$buffer ( $\mathrm{pH} 2.2$ ).

The compounds present in the final extract were analyzed on a high pressure liquid chromatograph (HPLC) with a sulfonated divinylbenzene polystyrene cation exchange column (Dionex DC-5A resin in a $4 \mathrm{~mm} \times 15 \mathrm{~cm}$ stainless steel column) with $o$-phthalaldehyde (Benson and Hare, 1975) fluorescence detection. This procedure is capable of detecting compounds containing primary amino groups, such as amino acids and many peptides. Quantitation was based on peak heights compared with the $n$-leucine internal standard. All release rates were corrected for differences in response and recovery.

Localization experiments. All of the localization experiments were done on cats. The tracers used were $D$ $\left[{ }^{3} \mathrm{H}\right]$ aspartate and $\mathrm{D}-\left[{ }^{3} \mathrm{H}\right]$ glutamate, intended to be labels for acidic amino acid pathways (Streit, 1980). Cats were anesthetized, paralyzed, held in a stereotaxic apparatus, and maintained on a respirator. The receptive field properties of cells at the injection sites were determined by extracellular recording and stimulation with a hand-held projector on a tangent screen. The labeled compound (20 to $200 \mu \mathrm{Ci}$ in 0.5 to $1 \mu \mathrm{l}$ of buffered saline) then was pressure injected from the recording pipette (Kelly and Gilbert, 1975). The cat was resuscitated and, after 1 to 2 days, re-anesthetized and perfused with a fixative containing $2 \%$ glutaraldehyde and $1 \%$ formaldehyde in a phosphate buffer, $\mathrm{pH} 7.4$. Blocks of brain were removed, allowed to sink in a $30 \%$ sucrose solution of the above fixative, and sectioned on a freezing microtome. The sections then were processed for autoradiography. This technique was used to make injections of $\mathrm{D}-\left[{ }^{3} \mathrm{H}\right]$ aspartate in the LGN (three experiments), superior colliculus (three experiments), cortical area 17 (three experiments), and cortical area 19 (one experiment). D- $\left[{ }^{3} \mathrm{H}\right]$ Glutamate was injected into the LGN (two experiments) and superior colliculus (two experiments).

D- $\left[{ }^{3} \mathrm{H}\right]$ Aspartate $(16 \mathrm{Ci} / \mathrm{mmol})$ was obtained from New England Nuclear. D- $\left[{ }^{3} \mathrm{H}\right]$ Glutamate $(19 \mathrm{Ci} / \mathrm{mmol})$ was prepared from a D-glutamate-enriched $\mathrm{D}, \mathrm{L}$-glutanate mixture (New England Nuclear) by means of L-aminoacid oxidase (Parikh et al., 1957). Veratridine was obtained from Sigma Chemical Co. and tetrodotoxin was from Calbiochem.

\section{Results}

Tissue slice release. A trace of an HPLC analysis of the endogenous, primary amino-containing compounds in the tissue slices is shown in Figure 1a. The concentrations observed are similar to those reported previously (Tallan et al., 1954). Although some of these compounds may be neurotransmitters of specific cell types, many clearly represent normal constituents of all tissues. Two independent means of depolarizing the tissue, intended to induce synaptic release, were used to determine which of the above compounds may act as neurotransmitters. Control experiments were carried out in the presence of the appropriate blocking agents in both cases. In the first procedure, the release in the presence of elevated $\mathrm{K}^{+}$and normal $\mathrm{Ca}^{2+}$ was compared with that observed with elevated $\mathrm{K}^{+}$and low $\mathrm{Ca}^{2+} /$ high $\mathrm{Mg}^{2+}$, which should block synaptic release. We refer to release in the first medium as stimulated release and release in the second medium as control release. Figure $1, b$ and $c$, shows HPLC traces of the release patterns obtained with the two media; in Table I, the release rates for identified compounds are shown; and Figure 2 gives the ratios for stimulated/ control release for these compounds. The release rates of aspartate, glutamate, and GABA are enhanced markedly, while those of the other compounds measured are rela tively unchanged. For aspartate, the release rate increased 12-fold; for glutamate, it increased 14-fold; and for GABA, it increased 6-fold. With normal medium, with medium containing low $\mathrm{Ca}^{2+} /$ high $\mathrm{Mg}^{2+}$ and normal $\mathrm{K}^{+}$, and with medium containing low $\mathrm{Ca}^{2+} /$ high $\mathrm{Mg}^{2+}$ and high $\mathrm{K}^{+}$, the release rates were similar (data not shown). In the second proccdure, the release was induced by 100 $\mu \mathrm{M}$ veratridine, which is known to open the voltagesensitive $\mathrm{Na}^{+}$channels, and for the control, the release was blocked with $10 \mu \mathrm{M}$ tetrodotoxin, a $\mathrm{Na}^{+}$channel blocker. The release rates obtained with this procedure also were increased most dramatically for aspartate, glutamate, and GABA as shown in Table II. The ratios for stimulated/control release are given in Figure 3.

It is of interest to note that, with either stimulation procedure, there was a much less marked increase in the release of taurine or glycine which also have been proposed as possible cortical transmitters (Curtis and Johnston, 1974). The resolution and the sensitivity of the 

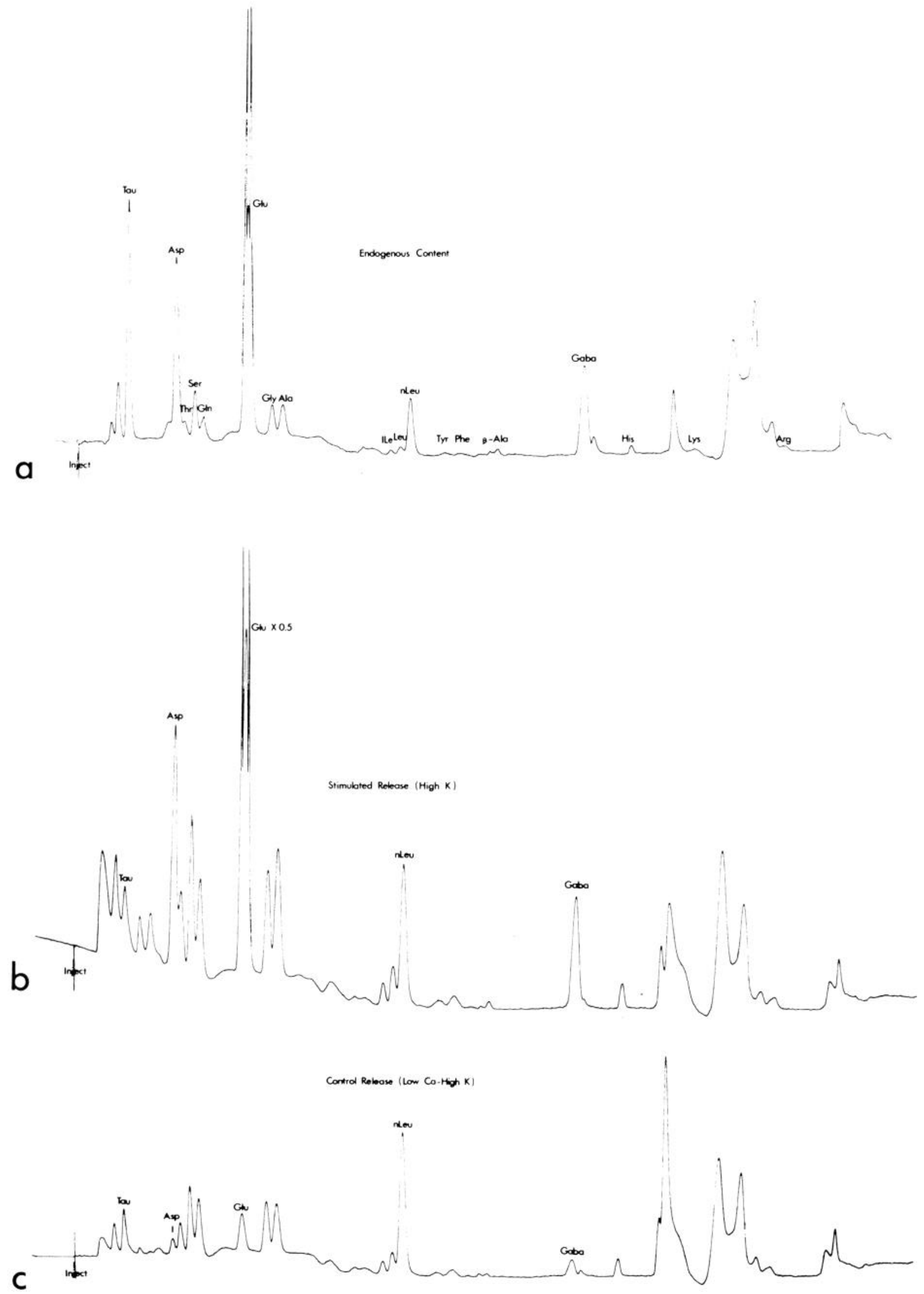

Figure 1. HPLC amino acid analyses. $a$, Compounds present in tissue slices of rat visual cortex; $b$, compounds released following stimulation with high potassium medium; $c$, compounds released under control conditions (see "Materials and Methods"). $n$ Leucine was added to all incubation media at $1 \mu \mathrm{m}$ as an internal standard. Bar $=10 \mathrm{~min}$. 
present procedure made it possible to analyze the release of several amino acids in addition to those that have been studied previously. As indicated above, none of these compounds showed marked increases in their release with the conditions of stimulation used.

Localization experiments. We attempted to label the cells that release aspartate and glutamate by retrograde filling following injections of $\mathrm{D}-\left[{ }^{3} \mathrm{H}\right]$ aspartate and $\mathrm{D}$ $\left[{ }^{3} \mathrm{H}\right]$ glutamate in the vicinity of their terminals (see "Discussion"). With this approach, one could label, in

TABLE I

Ratio of high potassium-stimulated to low calcium control release rate

\begin{tabular}{lcc}
\hline & \multicolumn{2}{c}{ Release Rate (5 min) } \\
\cline { 2 - 3 } & \multicolumn{2}{c}{ Stimulated $p$ Col/mg, wet wt. } \\
\hline Taurine & $40 \pm 13$ & $30 \pm 12$ \\
Aspartate & $269 \pm 46$ & $22 \pm 5$ \\
Threonine & $92 \pm 17$ & $42 \pm 6$ \\
Serine & $169 \pm 53$ & $87 \pm 21$ \\
Glutamine & $175 \pm 67$ & $145 \pm 21$ \\
Glutamate & $813 \pm 252$ & $56 \pm 10$ \\
Glycine & $115 \pm 14$ & $59 \pm 12$ \\
Alanine & $150 \pm 29$ & $70 \pm 12$ \\
Valine & $22 \pm 4$ & $27 \pm 20$ \\
Isoleucine & $16 \pm 4$ & $9 \pm 2$ \\
Leucine & $34 \pm 12$ & $18 \pm 4$ \\
Tyrosine & $16 \pm 5$ & $11 \pm 3$ \\
Phenylalanine & $17 \pm 5$ & $10 \pm 2$ \\
$\beta$-Alanine & $9 \pm 4$ & $6 \pm 4$ \\
GABA & $226 \pm 51$ & $41 \pm 12$ \\
Histidine & $20 \pm 4$ & $14 \pm 5$ \\
Lysine & $46 \pm 10$ & $32 \pm 15$ \\
Arginine & $24 \pm 13$ & $15 \pm 4$ \\
\hline
\end{tabular}

principle, cortical cells having locally ramifying axons by making intracortical injections or label cells with distant projections by making the injections in their efferent targets. All cortical neurons have terminals in the immediate cortical area, and some, notably the pyramidal and spiny stellate cells, also project to distant sites. Injections of the labeled compounds were made in area 17 (the primary visual cortex) and in other regions with particularly heavy interconnections with it, including the LGN, superior colliculus, and area 19 (see the introduction for a brief description of these pathways). The most striking result was that obtained after the LGN injection (Fig. 4). In the topographically appropriate region, many pyramidal cells in cortical layer 6 were labeled and there was a diffuse band of label in layer 4 . Injection of $\mathrm{D}$ $\left[{ }^{3} \mathrm{H}\right]$ glutamate produced a similar result (Fig. 5), although the background labeling was heavier and it was difficult to distinguish a band of label in layer 4. In marked contrast to these results, injections of either labeled compound in the dorsal layers of the superior colliculus, the site of projection of cortical layer 5 cells, produced no labeling at all in the visual cortex. After injections of $\mathrm{D}-\left[{ }^{3} \mathrm{H}\right]$ aspartate in area 19 , there were a few labeled cells in the superficial layers of area 17. Thus, of the cells participating in the principal efferent pathways of the visual cortex, the layer 6 cells appear to be associated most strongly with uptake and transport of D-aspartate and D-glutamate.

Further evidence for the association of layer 6 pyramidal cells with uptake of aspartate and glutamate was obtained by making $\mathrm{D}-\left[{ }^{3} \mathrm{H}\right]$ aspartate injections directly in area 17 and observing the local labeling pattern (Fig. $6 a$ ). In the region of cortex immediately surrounding the injection site, labeled cells were found predominantly in the deeper layers, with the highest concentration in layer 6. Although there was heavy background labeling due to

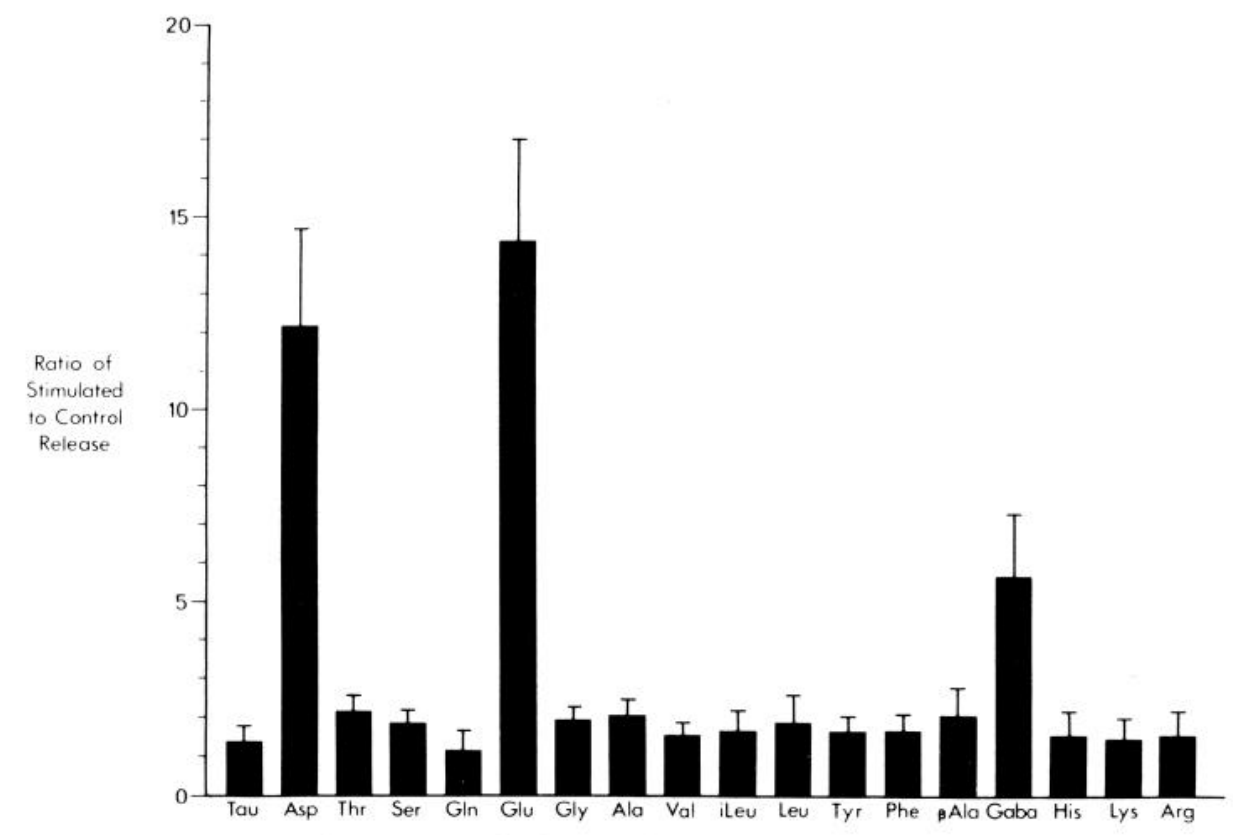

Figure 2. Ratios of the rates of release of endogenous amino acids for potassiumstimulated versus low calcium control conditions (from Table I). 
the injection, a diffuse band of label was visible in layer 4. A similar pattern was observed following a local injection into area 19 (Fig. 6c). From previous results (Gilbert and Kelly, 1975), it is known that layer 6 cells in area 19 project not only to the thalamus but to area 17 as well. In fact, a few cells in layer 6 of area 19 were labeled after the injection of $\mathrm{D}-\left[{ }^{3} \mathrm{H}\right]$ aspartate in area 17.

The present series of experiments also made it possible to test for the existence of aspartate- and glutamateaccumulating cells in the subcortical visual pathways. For example, in the LGN, we were unable to label cells either with local injections (Fig. 7, $a$ to $c$ ) or with retrograde filling following cortical injections (Fig. 8, $a$ to $d$ ). With local injections in the superior colliculus, on the other hand, there were numerous labeled cells through-

TABLE II

Ratio of veratridine-stimulated to tetrodotoxin control release rate

\begin{tabular}{|c|c|c|}
\hline & \multicolumn{2}{|c|}{ Release Rate ( $5 \mathrm{~min}$ ) } \\
\hline & Stimulated & Control \\
\hline & \multicolumn{2}{|c|}{$\mathrm{pmol} / \mathrm{mg}$, wet wt. } \\
\hline Taurine & $34 \pm 10$ & $11 \pm 5$ \\
\hline Aspartate & $234 \pm 39$ & $27 \pm 17$ \\
\hline Threonine & $149 \pm 24$ & $64 \pm 22$ \\
\hline Serine & $243 \pm 89$ & $150 \pm 75$ \\
\hline Glutamine & $573 \pm 92$ & $175 \pm 30$ \\
\hline Glutamate & $502 \pm 87$ & $15 \pm 7$ \\
\hline Glycine & $191 \pm 76$ & $88 \pm 54$ \\
\hline Alanine & $194 \pm 55$ & $91 \pm 36$ \\
\hline Valine & $22 \pm 9$ & $18 \pm 4$ \\
\hline Isoleucine & $22 \pm 6$ & $14 \pm 7$ \\
\hline Leucine & $45 \pm 7$ & $27 \pm 12$ \\
\hline Tyrosine & $41 \pm 14$ & $30 \pm 11$ \\
\hline Phenylalanine & $22 \pm 5$ & $15 \pm 5$ \\
\hline$\beta$-Alanine & $9 \pm 2$ & $4 \pm 2$ \\
\hline GABA & $289 \pm 80$ & $8 \pm 6$ \\
\hline Histidine & $13 \pm 11$ & $9 \pm 8$ \\
\hline Lysine & $17 \pm 12$ & $12 \pm 7$ \\
\hline Arginine & $15 \pm 11$ & $13 \pm 4$ \\
\hline
\end{tabular}

out the area surrounding the injection site (Fig. 9). No labeled cells were seen in the ganglion cell layer of the retina after injections of $\mathrm{D}-\left[{ }^{3} \mathrm{H}\right]$ aspartate in either the LGN or superior colliculus.

In addition to specific retrograde transport and local uptake of $\mathrm{D}-\left[{ }^{3} \mathrm{H}\right]$ aspartate, we have evidence indicating that there is specific anterograde transport of this compound. Following an injection in area 17, a diffuse patch of labeling appeared in the retinotopically appropriate site in the LGN (Fig. 8a). This is unlikely to be due to retrograde transport because of the absence of cell body labeling in the LGN and instead must represent labeling of the corticogeniculate terminals originating from the cells in layer 6 . On the other hand, following cortical injections, there was no label in the colliculus at the site of projection of the cortical layer 5 cells.

\section{Discussion}

The present results provide evidence that aspartate and glutamate may act as transmitters in the visual cortex, in particular, for the cells in layer 6 . The first suggestion that these compounds might be involved in vertebrate central synaptic transmission came from the observation that they excite most cortical neurons (Hayashi, 1954; Krnjevic and Phillis, 1963). Later studies showed that they are released from the cortical surface upon electrical stimulation in various subcortical areas (Jasper and Koyama, 1969) or by application of potassium to the cortex (Clark and Collins, 1976). Electrically induced release of endogenous compounds from tissue slices of olfactory cortex also has suggested a role for either glutamate (Bradford and Richards, 1976) or aspartate (Collins, 1979) as a transmitter in the lateral olfactory tract. High affinity uptake systems, which may be associated with neurotransmitter inactivation, have been demonstrated for aspartate and glutamate in synaptosomal (Logan and Snyder, 1972) and slice preparations (Balcar and Johnston, 1972) of rat cerebral cortex.

In the present investigation, with tissue slices from

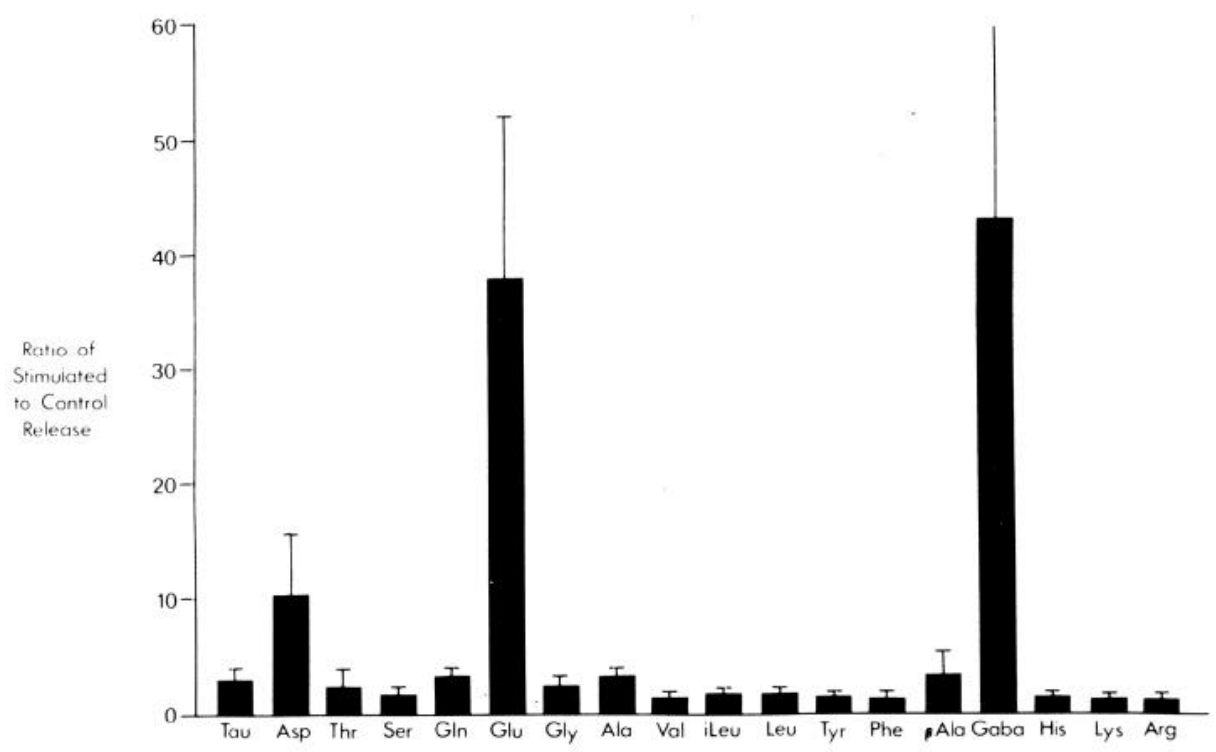

Figure 3. Ratios of the rates of release of endogenous amino acids for veratridinestimulated versus tetrodotoxin control conditions (from Table II). 

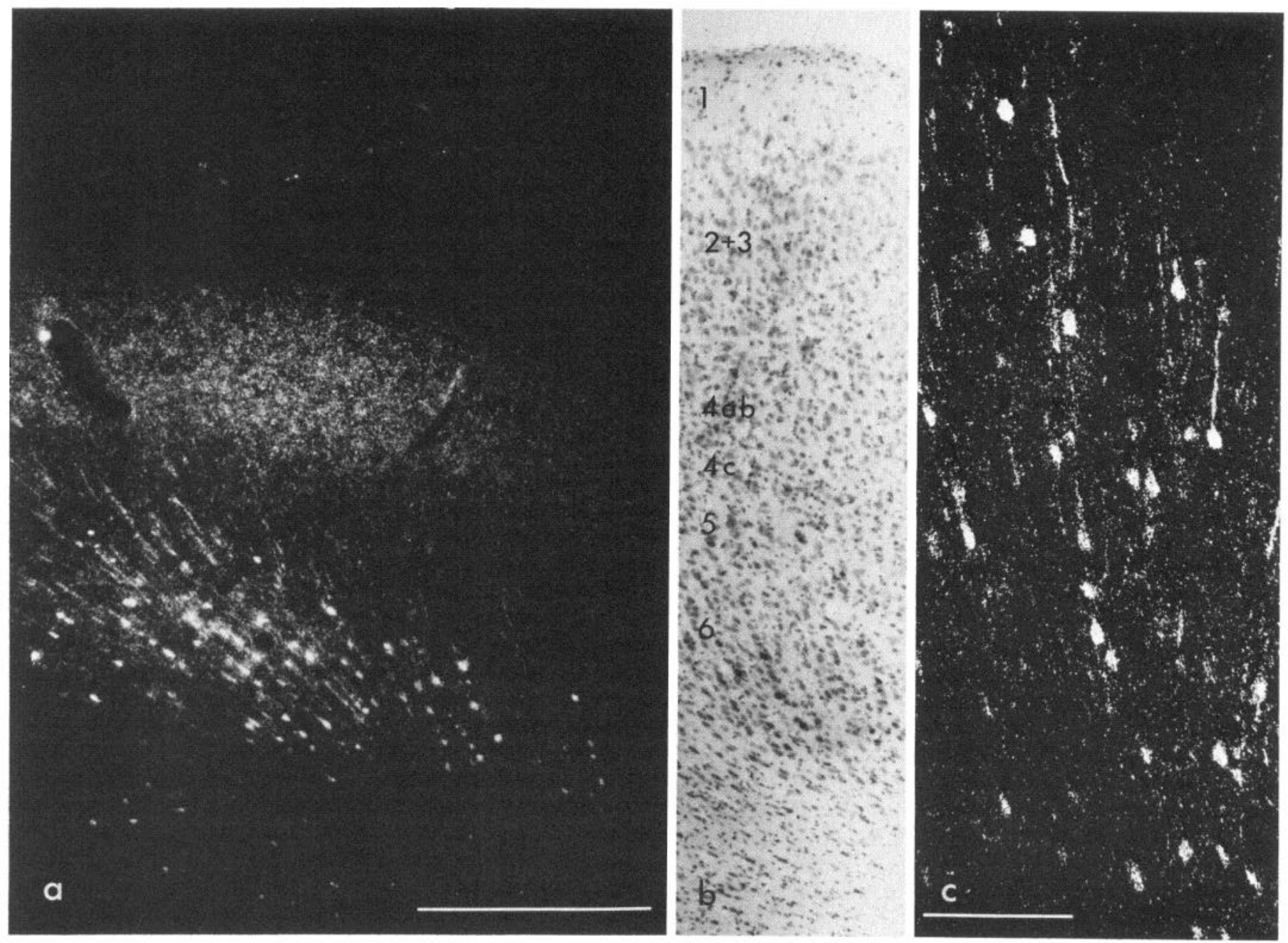

Figure 4. Cells in cortical layer 6 labeled by retrograde filling following injection of $\mathrm{D}-\left[{ }^{3} \mathrm{H}\right]$ aspartate in the LGN. $a$, Dark-field photomicrograph showing labeled cells in layer 6 and a band of diffuse label in layer $4 . B a r=500 \mu \mathrm{m}$. $b$, Bright-field photomicrograph of the right side of field shown in $a$, indicating positions of layers. $c$, Higher power dark-field photomicrograph of labeled layer 6 cells, indicating pyramidal morphology. Bar $=100 \mu \mathrm{m}$.

visual cortex, we have demonstrated that, of 18 amino acids that were detectable, the release of aspartate, glutamate, and GABA was increased markedly with chemical depolarization. Two independent means of depolarizing the tissue were used, elevated extracellular $\mathrm{K}^{+}$and veratridine. Increasing extracellular $\mathrm{K}^{+}$should depolarize glia as well as neurons, but the requirement that induced release be blocked in low $\mathrm{Ca}^{2+} /$ high $\mathrm{Mg}^{2+}$ medium increases the likelihood that the observed release is synaptic in origin and is not a nonspecific release simply related to membrane depolarization. With veratridineinduced release, compared with $\mathrm{K}^{+}$-stimulated release, the ratio of stimulated to control release was similar for aspartate but higher for glutamate and GABA. As can be seen from Tables I and II, this effect was caused by a decrease in the release of glutamate and GABA in the tetrodotoxin control experiment. It is unclear whether this result has any functional significance, but it does indicate that the release of aspartate and glutamate are not controlled identically under all conditions.

Of the compounds studied in the release experiments, the three most likely neurotransmitter candidates are aspartate, glutamate, and GABA. Earlier studies have dealt with the localization of GABA through uptake and autoradiography (Hokfelt and Ljundahl, 1972; Chronwall and Wolff, 1978; Davis et al., 1977) and through immunohistochemical localization of the GABA synthetic enzyme glutamic acid decarboxylase (Ribak, 1978). In the present study, we have focused on the localization of cells that may use aspartate and glutamate. Previous attempts have been made to localize these compounds to particular pathways in the central nervous system by making a lesion at the source of a pathway and then looking at the terminal region for decreases in endogenous content, high affinity uptake, and release (Nadler et al., 1976; LundKarlsen and Fonnum, 1978). Cellular localization of particular neurons using these compounds as transmitters, however, has been difficult. It is possible to visualize terminals that take up L-glutamate with high affinity using electron microscopic autoradiography (Storm-Mathiesen and Iversen, 1979), but the labeling of cell bodies with L-glutamate or L-aspartate is more difficult, possibly because metabolism of the amino acid takes place before sufficient label is transported to them. The $\mathrm{D}$ forms of 




Figure 5. Bright-field photomicrograph showing cells in cortical layer 6 labeled by retrograde filling following injection of D$\left[{ }^{3} \mathrm{H}\right]$ glutamate in the LGN. Layers 5 and 6 and white matter $(W)$ are shown. $B a r=100 \mu \mathrm{m}$.

these amino acids, however, when taken up are not metabolized. D- $\left[{ }^{3} \mathrm{H}\right]$ Aspartate, which is accumulated by the same high affinity mechanism that is responsible for uptake of L-aspartate and L-glutamate (Davies and Johnston, 1976), thus can be used to label cells even after the long survival times required for retrograde labeling of long pathways (Streit and Cuenod, 1979; Beaudet et al., 1980; Streit, 1980). Although D-glutamate is not taken up as readily by the high affinity mechanism, it may still be possible to use it as a tracer for cellular localization. Release and uptake experiments provide two independent lines of evidence suggesting the role of a compound in neurotransmission. It is important, however, to establish that the release and uptake are localized to the same cells. Previous experiments indicate that $\mathrm{D}-\left[{ }^{3} \mathrm{H}\right]$ aspartate accumulated by the high affinity uptake system can be released with depolarization in a calcium-dependent manner, suggesting that, for this compound, the uptake process does label the same pool that is used for release (Malthe-Sorenssen et al., 1979).

We have made use of retrograde labeling, as well as local injections and anterograde labeling, to demonstrate that, in visual cortex, accumulation of aspartate and glutamate is particularly associated with layer 6 pyramidal cells that participate in the recurrent projection to the LGN. These cells possess extensive axonal ramifica- tions in layer 4 as well as in layer 6 (Gilbert and Wiesel, 1979). Given this, one might expect diffuse labeling to occur in layer 4, as is indeed the case. There is, however, another possible explanation for the band of diffuse label in layer 4, which is filling of the terminals of the LGN principal neurons either by anterograde transport following injections in the LGN or by direct uptake following local injections in cortex. Although we have no evidence to distinguish definitively between these two possibilities, several results suggest that the band, in fact, is derived from the collaterals of layer 6 cell axons. First, if one makes an injection of $\mathrm{D}-\left[{ }^{3} \mathrm{H}\right]$ aspartate in area 17 and looks in the LGN, there are no labeled cell bodies, but there is a patch of diffuse label at the topographically appropriate site. This demonstrates that $(a)$ the LGN principal cells do not transport t'.1e label retrogradely from the cortex to their perikarya in the LGN and $(b)$ the layer 6 cells, when labeled by a cortical injection, apparently are able to transport the label anterogradely to their terminals in the LGN. This, in turn, suggests, respectively, that $(a)$ the LGN terminals in the cortex do not take up the label and $(b)$ the layer 6 cells, when labeled retrogradely by an LGN injection, should be able further to transport the label anterogradely to their collaterals in layer 4. Secondly, if one examines the local labeling pattern following an injection into the LGN, 

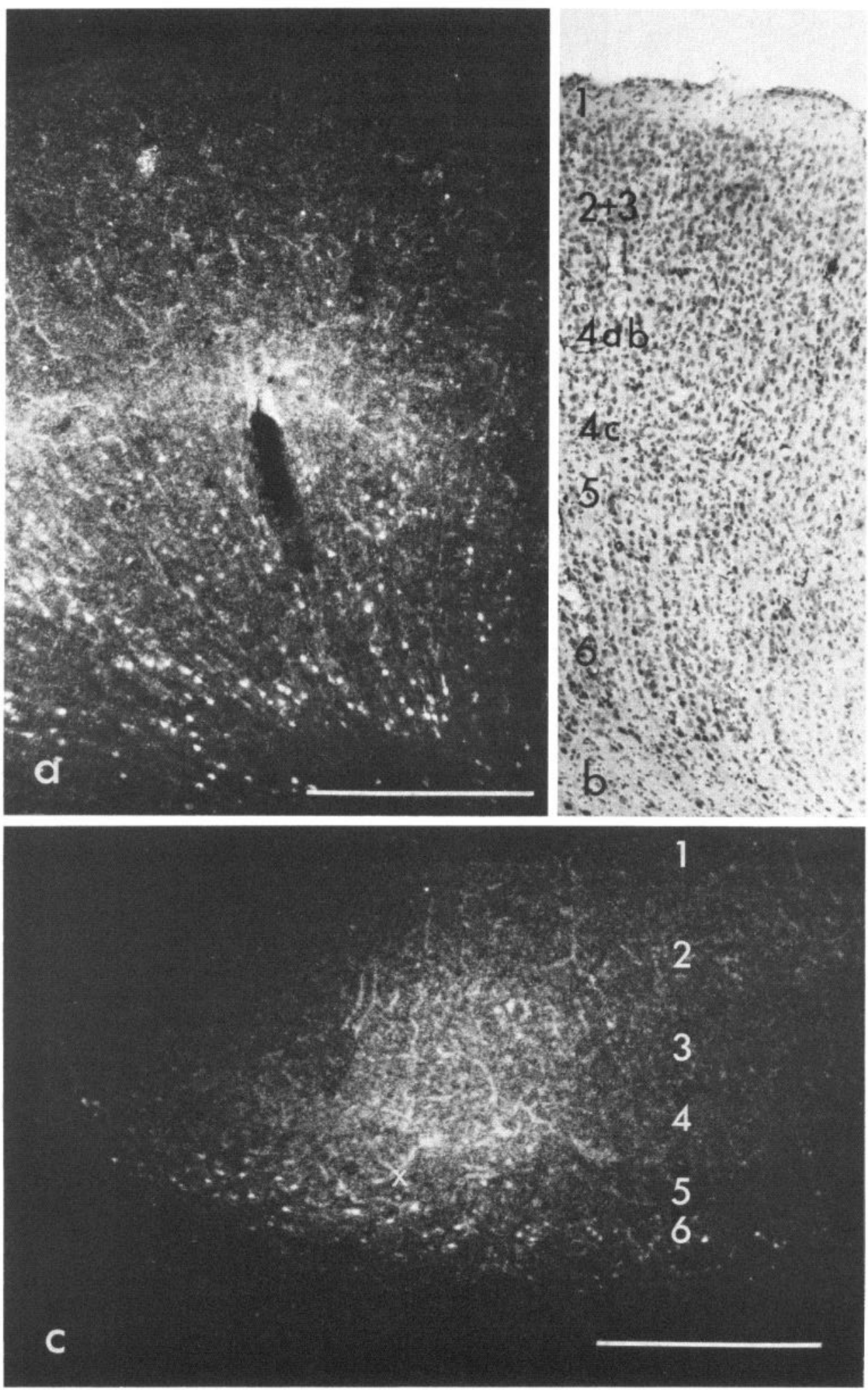

Figure 6. Labeling pattern observed in the cortex after local injections of $\mathbf{D}-\left[{ }^{3} \mathrm{H}\right]$ aspartate. $a$, Dark-field photomicrograph of area 17 showing labeled cells in layer 6 and elevated density of diffuse label in layer 4. Note the absence of labeled cells in the superficial layers. Bar $=500$ $\mu \mathrm{m}$. $b$, Bright-field photomicrograph of the right side of the field shown in $a$, indicating positions of layers. $c$, Dark-field photomicrograph of area 19 showing distribution of the label after local injection of $\mathrm{D}-\left[{ }^{3} \mathrm{H}\right]$ aspartate. Labeled cells are restricted to layer $6 . \mathrm{Bar}=500 \mu \mathrm{m}$. 

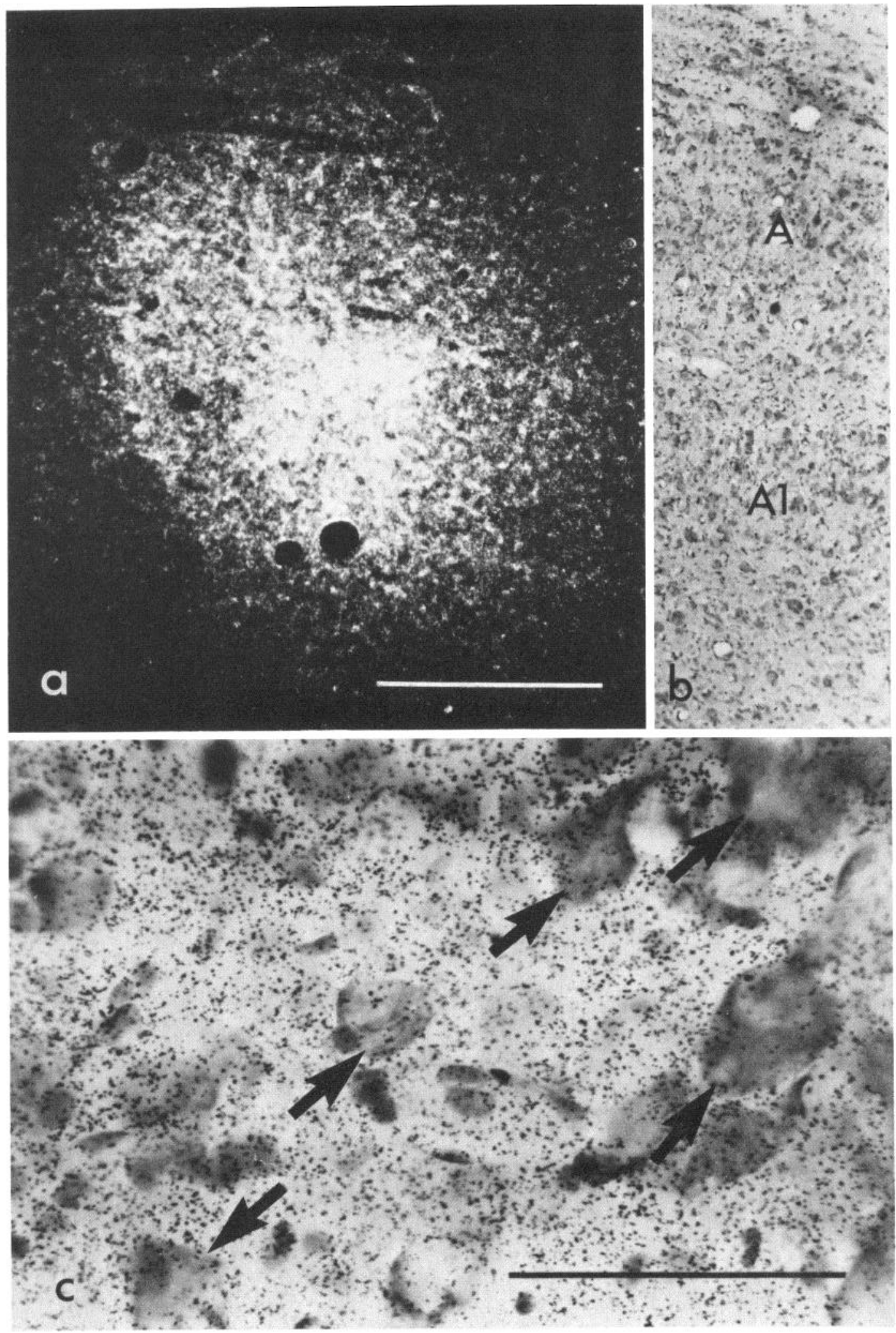

Figure 7. Label in LGN following local injection of $\mathrm{D}-\left[{ }^{3} \mathrm{H}\right]$ aspartate. $a$, Dark-field photomicrograph showing diffuse distribution of the label. $B a r=200 \mu \mathrm{m}$. $b$, Bright-field photomicrograph of the right side of the field shown in $a$, indicating positions of geniculate laminae. $c$, Higher power photomicrograph of the field shown in $a$, demonstrating the absence of the label overlying cell bodies (arrows). Bar $=100 \mu \mathrm{m}$. 

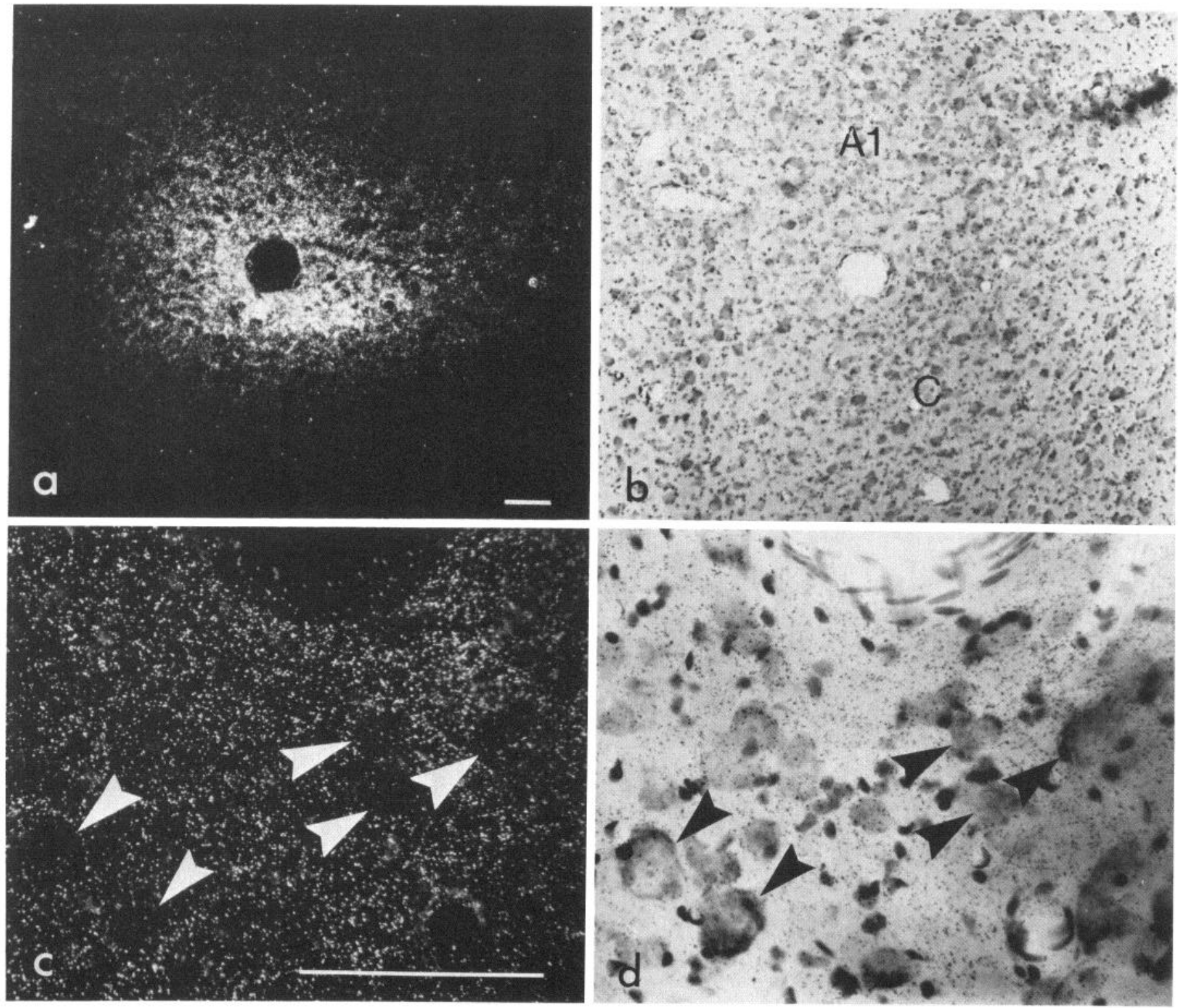

Figure 8. Distribution of the label in LGN following an injection in area 17. $a$, Photomicrograph of the label in laminae A1, showing diffuse distribution. $b$, Bright-field photomicrograph of the same field as in $a$, indicating positions of geniculate layers $A 1$ and $C$. $c$, Higher power dark-field photomicrograph of a portion of the patch of label shown in $a$, with arrowheads indicating small patches lacking label. $d$, Bright-field photomicrograph of the field shown in $c$, with arrowheads indicating the presence of cell bodies in the positions of the label-free patches. Bars $=100 \mu \mathrm{m}$.

once again there is only diffuse labeling with an absence of labeled cell bodies. This indicates that, in the LGN, the principal cells do not accumulate the label and, therefore, presumably cannot transport it to their terminals in layer 4 in the cortex. These results also suggest that anterograde transport may complement retrograde transport in the mapping of transmitter-specific pathways in the brain. In this regard, it is of interest that anterograde labeling with $\mathrm{D}-\left[{ }^{3} \mathrm{H}\right]$ aspartate also has been demonstrated in part of the retinotectal pathway in the pigeon (Beaudet et al., 1980).

Although the corticogeniculate pathway was labeled readily both anterogradely and retrogradely, neither approach produced any sign of labeling in the layer 5 cells participating in the corticocollicular pathway. From pre- vious studies, it has been suggested that, for both the corticogeniculate and corticocollicular pathways, the transmitter is glutamate (Lund-Karlsen and Fonnum, 1978). This suggestion is based on the finding that, following cortical ablation, the endogenous level of glutamate, but not of aspartate, decreases in both the geniculate and colliculus. The fact that we do not observe labeling of layer 5 cells after collicular injections casts doubt on the idea that this pathway uses glutamate as its transmitter. It is conceivable that we did not find the appropriate conditions to observe the labeling, but this is unlikely since a range of injection volumes and survival times were tried. At the injection sites in the superior colliculus, we did see many labeled cells, and it is possible that the changes in endogenous glutamate levels ob- 


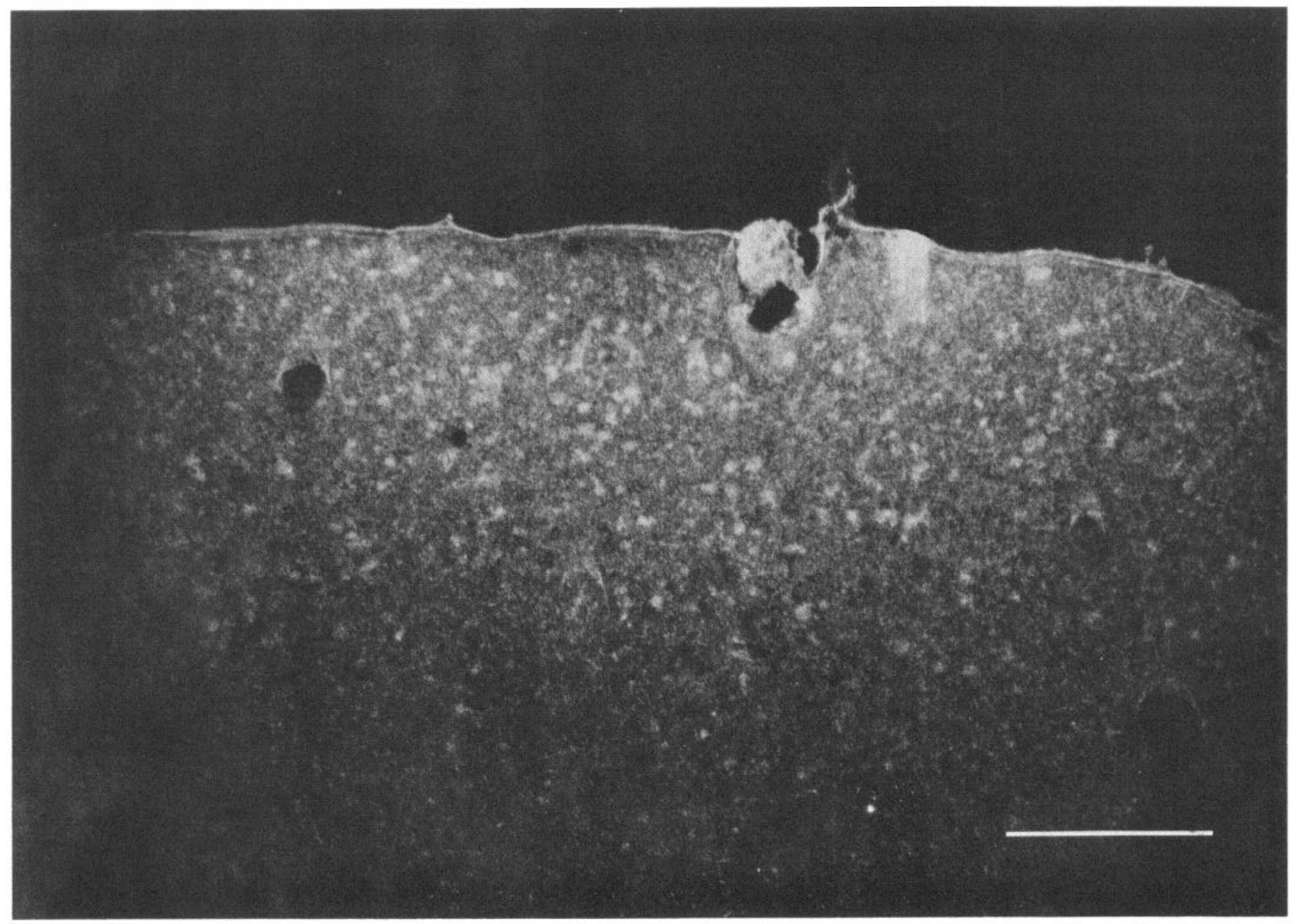

Figure 9. Label in the superior colliculus following local injection of $\mathrm{D}-\left[{ }^{3} \mathrm{H}\right]$ aspartate. Both diffuse label and labeled cell bodies are present. $B a r=200 \mu \mathrm{m}$.

served after cortical ablation are associated with transsynaptic effects in these cells. Another possibility is that there is a species difference between cats, used in the present labeling of pathways, and rats, used in the cortical ablation experiments, although this also seems unlikely. The release results, furthermore, clearly indicate that some cells in the cortex do release aspartate, and taken together with local cortical injections of $D-\left[{ }^{3} \mathrm{H}\right]$ aspartate, they suggest that the layer 6 cells are likely candidates for at least part of the endogenous aspartate release.

Throughout we have used the terms "uptake" and "transport" or "filling" to describe the process by which the cells are labeled following injections of $D-\left[{ }^{3} \mathrm{H}\right]$ aspartate and $\mathrm{D}-\left[{ }^{3} \mathrm{H}\right]$ glutamate. In fact, the results described give no evidence as to whether there is net uptake of aspartate or glutamate, as opposed to some form of exchange, or whether there is an active intracellular transport process, as opposed to passive diffusion. Regarding the uptake process, it is of interest to note that labeling with $\mathrm{D}-\left[{ }^{3} \mathrm{H}\right]$ aspartate, which, as described earlier, is taken up by the high affinity uptake system, appears to be more efficient than labeling with $\mathrm{D}-\left[{ }^{3} \mathrm{H}\right]$ glutamate, which does not interact as well with the high affinity system. In the present experiments, the distribution of the labeled cells in cortical layer 6 seen after injections of $\mathrm{D}-\left[{ }^{3} \mathrm{H}\right]$ glutamate in the LGN and that seen after $\mathrm{D}-\left[{ }^{3} \mathrm{H}\right]$ aspartate injections were similar, but we have no evidence to indicate whether or not the same cells are labeled by both compounds.

With respect to the mechanism of intracellular translocation of the labeled compounds, we have found that, for successful filling, post-injection survival times are required that are long enough for passive diffusion to play a significant role. For example, following injections in the LGN, survival times of $24 \mathrm{hr}$ gave satisfactory filling in cortical layer 6 cells located about $2 \mathrm{~cm}$ away. From cytoplasmic diffusion coefficients measured for GABA and acetylcholine (Koike and Nagata, 1979), at a site $2 \mathrm{~cm}$ from the region of initial labeling, the cytoplasmic concentration of the label at $24 \mathrm{hr}$ should equal approximately $10 \%$ of that initially present at the site of injection. It is difficult to estimate the cytoplasmic concentrations of labeled compounds from autoradiographs, but a difference of about 10 -fold in exposure times is required to produce a similar labeling density in the cortex and at the injection site in the LGN. Passive diffusion thus could account for a large part of the 
movement of the labeled compounds in the present experiment. If passive diffusion is the means of intracellular translocation, then the observed specificity of labeling must be associated with the uptake process. This is not unreasonable, since it is well established that the high affinity uptake systems present in brain have a high degree of molecular specificity.

In evaluating a putative transmitter, the key question is whether it is the true transmitter, a metabolite of the true transmitter, or is simply mimicking the true transmitter. Many lines of evidence, such as high affinity uptake of exogenously applied compounds, are incapable of distinguishing between these possibilities. The fact, as shown in the present study, that endogenous aspartate and glutamate are both released in a calcium-dependent manner suggests that these compounds in some way are involved in neurotransmission. Such results, however, do not rule out the possibility that they may be metabolites of the true transmitter. Additional evidence for the direct role of aspartate and glutamate as neurotransmitters is provided by physiological studies using iontophoretic or topical application of thesc substances on or within the cortex (Hayashi, 1954; Krnjevic and Phillis, 1963; Krnjevic and Schwartz, 1967) which demonstrate that both compounds are excitatory and increase membrane conductance of cortical neurons. While this still does not rule out the possibility that these compounds are transmitter metabolites that retain the ability to excite cells, it makes more plausible the idea that they actually are neurotransmitters.

In summary, the list of criteria for aspartate and glutamate as cortical neurotransmitters now has been extended to include (1) presence of the compound, (2) release of endogenous material under conditions specifically intended to induce synaptic release, (3) high affinity uptake as a means of inactivation or possibly of accumulating precursor, (4) cellular localization, and (5) a postsynaptic effect. In the present case, further studies are required to show that the postsynaptic effect obtained by iontophoretic application of these substances in the LGN is the same as that obtained by activation of the layer 6 cells. Demonstration that aspartate and glutamate are involved in the recurrent projection from the cortex to the lateral geniculate nucleus and in the projection within the cortex from layer 6 to layer 4 should be useful in determining the role of these pathways in cortical and geniculate function.

\section{References}

Balcar, V. J., and G. A. R. Johnston (1972) 'T'he structural specificity of the high affinity uptake of L-glutamate and Laspartate by rat brain slices. J. Neurochem. 19: 2657-2666.

Baughman, R. W., and C. D. Gilbert (1980) Aspartate and glutamate as possible neurotransmitters of cells in layer 6 of the visual cortex. Nature 287: 848-849.

Beaudet, A., A. Burkhalter, J. C. Reubi, and M. Cuenod (1980) Selective axonal transport of ${ }^{3} \mathrm{H}$-D-aspartate in the pigeon retinotectal pathway. Experientia 36: 692.

Benson, J. R., and P. E. Hare (1975) o-Pthalaldehyde: Fluorogenic detection of primary amines in the picomole range. Comparison with fluorescamine and ninhydrin. Proc. Natl. Acad. Sci. U. S. A. 72: 619-622.

Bradford, H. F., and C. D. Richards (1976) Specific release of endogenous glutamate from piriform cortex stimulated in vitro. Brain Res. 105: 168-172.

Chronwall, B. M., and J. R. Wolff (1978) Classification and location of neurons taking up 3H-GABA in the visual cortex of rats. In Amino Acids as Chemical Transmitters, F. Fonnum, ed., pp. 297-303, Plenum, New York.

Clark, R. M., and G. G. S. Collins (1976) The release of endogenous amino acids from the rat visual cortex. J. Physiol. (Lond.) 262: 383-400.

Collins, G. G. S. (1979) Evidence of a neurotransmitter role for aspartate and gamma-aminobutyric acid in the rat olfactory cortex. J. Physiol. (Lond.) 291: 51-60.

Curtis, D. R., and G. A. R. Johnston (1974) Amino acid transmitters in the mammalian central nervous system. Ergeb. Physiol. Biol. Chem. Exp. Pharmakol. 69: 97-188.

Davies, L. P., and G. A. R. Johnston (1976) Uptake and release of D- and L-aspartate by rat brain slices. J. Neurochem. 26: 1007-1014.

Davis, T. L., K. Turlejski, and P. Sterling (1977) Identification by serial microscopic autoradiography of neurons in cortical area 17 that differentially accumulate exogenous ${ }^{3} \mathrm{H}$-gammaaminobutyric acid. Invest. Ophthalmol. Vis. Sci. Suppl. 27.

Gilbert, C. D., and J. P. Kelly (1975) The projections of cells in different layers of the cat's visual cortex. J. Comp. Neurol. 163: 81-105.

Gilbert, C. D., and T. N. Wiesel (1979) Morphology and intracortical projections of functionally characterized neurons in the cat visual cortex. Nature 280: 120-125.

Hayashi, T. (1954) Effects of sodium glutamate on the nervous system. Keio J. Med. 3: 183-192.

Hokfelt, T., and A. Ljundahl (1972) Autoradiographic identification of cerebral and cerebellar cortical neurons accumulating labeled gamma-aminobutyric acid ( $\left.{ }^{3} \mathrm{H}-\mathrm{GABA}\right)$. Exp. Brain Res. 14: 354-362.

Jasper, H. H., and I. Koyama (1969) Rate of release of amino acids from the cerebral cortex as affected by brainstem and thalamic stimulation. Can. J. Physiol. Pharmacol. 47: 889905.

Kelly, J. P., and C. D. Gilbert (1975) The projections of different morphological types of ganglion cells in the cat retina. $J$. Comp. Neurol. 163: 65-80.

Koike, H., and Y. Nagata (1979) Intra-axonal diffusion of $\left[{ }^{3} \mathrm{H}\right]$ acetylcholine and $\left[{ }^{3} \mathrm{H}\right]$ gamma-aminobutyric acid in a neurone of Aplysia. J. Physiol. (Lond.) 295: 397-417.

Krnjevic, K., and J. W. Phillis (1963) Iontophoretic studies of neurones in the mammalian cerebral cortex. J. Physiol. (Lond.) 165: 274-304.

Krnjevic, K., and S. Schwartz (1967) Some properties of unresponsive cells in the cerebral cortex. Exp. Brain Res. 3: 306319.

Logan, W. J., and S. H. Snyder (1972) High affinity uptake systems for glycine, glutamic and aspartic acids in synaptosomes of rat central nervous tissues. Brain Res. 42: 413-431.

Lund-Karlsen, R., and F. Fonnum (1978) Evidence for glutamate as a neurotransmitter in the corticofugal fibers to the dorsal lateral geniculate body and the superior colliculus in rats. Brain Res. 151: 457-467.

Malthe-Sorenssen, D., K. K. Skrede, and F. Fonnum (1979) Calcium dependent release of $\mathrm{D}-\left[{ }^{3} \mathrm{H}\right]$ aspartate evoked by selective electrical stimulation of excitatory afferent fibers to hippocampal pyramidal cells in vitro. Neuroscience 4: 12551263.

Nadler, J. V., K. W. Vaca, W. F. White, G. S. Lynch, and C. W. Cotman (1976) Aspartate and glutamate as possible neurotransmitters of excitatory hippocampal afferents. Nature 260: 538-540.

Parikh, J. R., J. P. Greenstein, M. Winitz, and S. M. Birnbaum (1957) The use of amino acid oxidases for the small-scale 
preparation of the optical isomers of amino acids. J. Am. Chem. Soc. 80: 953-958.

Ribak, C. E. (1978) Aspinous and sparsely spinous stellate neurons in visual cortex of rats contain glutamic acid decarboxylase. J. Neurocytol. 7: 461-478.

Storm-Mathieson, J., and L. L. Iversen (1979) Uptake of $\left[{ }^{3} \mathrm{H}\right]$ glutamic acid in excitatory nerve endings: Light and electronmicroscopic observations in the hippocampal formation of the rat. Neuroscience 4: 1237-1253.
Streit, P. (1980) Selective retrograde labeling indicating the transmitter of neuronal pathways. J. Comp. Neurol. 191: 429463.

Streit, P., and M. Cuenod (1979) Transmitter specificity and connectivity revealed by differential retrograde labeling of neural pathways. Neurosci. Lett. (Suppl.) 3: 340.

Tallan, H. H., S. Moore, and W. H. Stein (1954) Studies on the free amino acids and related compounds in the tissues of the cat. J. Biol. Chem. 211: 927-939. 